\title{
Aggregate Demand Disturbances in the Visegrad Group and the Eurozone
}

\author{
Krzysztof Beck, Jakub Janus
}

\begin{abstract}
A B S T R A C T
Objective: The main goal of the paper is to evaluate, in a comparative manner, the degree of similarities in aggregated demand disturbances in the Visegrad Group (the Czech Republic, Hungary, Poland and Slovakia, collectively: V4) and the Eurozone economies from 1995 to 2013.
\end{abstract}

Research Design \& Methods: The underlying demand disturbances are extracted using the structural vector auto-regression (SVAR) model with the long-run restrictions. The identification scheme is based on the theoretical aggregate supplyaggregate demand (AS-AD) model. The obtained approximations of unobservable demand shocks are then used to infer on their correlation structures.

Findings: The demand shocks among the four economies are described by the highest correlation among all chosen sub-samples. The dynamic approach revealed that the synchronization of the demand shocks in the V4 Group was stronger even when compared to the EMU core. The adjustments to the demand shocks in the V4 countries are relatively flexible and these economies converge to long-run equilibria at a fast pace.

Implications \& Recommendations: The V4 countries fulfil substantial criteria of an optimum currency area and could benefit from adoption of a single currency, as well as a common monetary policy.

Contribution \& Value Added: This comparative empirical study brings evidence on the similarities in aggregate demand shocks within the V4 and EMU countries.

\begin{tabular}{ll}
\hline Article type: & research paper \\
Keywords: & optimum currency area; economic shocks; SVAR; Visegrad Group \\
JEL codes: & E32, F15, F44, C32
\end{tabular}

Published by Centre for Strategic and International Entrepreneurship - Krakow, Poland

K. Beck's part of the article was prepared within the project "Convergence in countries and regions of the European Union" funded by the Polish National Science Centre, decision No. DEC-2011/01/N/HS4/03077.

\section{Suggested citation:}

Beck, K., \& Janus, J. (2013). Aggregate Demand Disturbances in the Visegrad Group and the Eurozone. Entrepreneurial Business and Economics Review, 1(3), 7-19. 


\section{INTRODUCTION}

The recent financial turmoil and economic downturn, along with the sovereign debt crisis, exposed significant institutional weaknesses of the Economic and Monetary Union (EMU). These events, however, also affected the Visegrad Group (V4) countries. In Poland, Hungary and the Czech Republic, the crisis led to the re-emergence of debates concerning the strategic decisions of euro adoption. In Slovakia, which joined the single currency area in 2009, there has been a discussion concerning the effects of euro on the macroeconomic performance in the last year. One of the key characteristics that allows to evaluate actual and potential benefits of a monetary union is the degree of similarity of aggregate shocks among integrating economies. In particular, the evidence on aggregate demand shocks distribution in V4 economies is helpful to answer the question whether a single monetary policy (one-size-fits-all) is advisable for the V4 Group as a whole, as well as for each of the countries.

The main goal of the paper is to evaluate, in a comparative manner, the degree of similarities in aggregated demand disturbances in the V4 and EMU economies from 1995 to 2013. The shocks are identified using the structural vector auto-regression (SVAR) model with the long-run, AS-AD restrictions. The obtained approximations of unobservable shocks are then used to infer on correlation structures of shocks and to build impulse response functions of output to these shocks. We specifically test the hypothesis that the similarity of macroeconomic shocks within the V4 Group has been greater than among the EMU countries.

The paper is structured as follows. Section 2 briefly reviews the developments in the optimum currency area (OCA) theory and empirical studies on macroeconomic shocks. Section 3 outlines the model used to identify the disturbances, along with data and their properties. Section 4 reports on the empirical results and provides a discussion. Section 5 concludes and underlines our basic findings.

\section{LITERATURE REVIEW}

Most of the initial works on the OCA theory were concerned with condition which an effectively performing monetary union must fulfil (Mundell, 1961; McKinnon, 1963; Kenen, 1969). It was proved that, in the absence of independent monetary policy and flexible exchange rates, member countries must either reveal symmetrical distribution of aggregate demand shocks or possess properly working alternative adjustment mechanisms (i.e. flexible wages/prices, mobile labour force or fiscal federalism). A high degree of symmetrical distribution was firstly attributed to economic openness and diversification of production in economies. Further research, however, provided a more dynamic analysis that led to two contradicting views (de Grauwe \& Mongelli, 2005). The first one, the 'European Commission View' (Commission of the European Communities 1990), later developed into the hypothesis of the endogeneity of optimum currency area criteria (Frankel \& Rose, 1998), states that integrating economies will be characterized with more symmetrical distribution of shocks, due to an increase in intra-industry trade. Opposite argument, known as the 'Krugman's View', suggests that on-going integration leads to a higher specialization in regions and causes distribution of shocks to be more idiosyncratic (Krugman, 1993). 
The main body of the empirical research on the OCA has been conducted through analyses of cyclical components of real GDP, as well as various factors that influence their coherence among countries. There is evidence that the business cycles synchronization in the EMU is affected by international trade, patterns of specialization and capital mobility (Lee \& Azali, 2010; Imbs, 2004; Kalemli-Ozcan, Papaioannou \& Peydro, 2009; Siedschlag, 2010; Silvestre, Mendonca \& Passos, 2009). Some authors indicate gravitational variables to be main drivers of cycles congruence (Baxter \& Koutraparitsas, 2004; Böwer \& Guillemineau, 2006), while others recognize the impact of structural similarities and congenial institutions on cycles correlation (Beck, 2014; Sachs \& Schleer, 2013). It has also been concluded that an increasing business cycles synchronization in Eurozone may be mainly attributed to global rather than regional tendencies (Bordo \& Helbling, 2011; Lehwald, 2012). Fidrmuc and Korhonen have identified 35 different publications that confirm a rather high correlation between business cycles in the EMU and Central and Eastern European Countrie (CEECs) (Fidrmuc \& Korhonen, 2006). On the other hand, Darvas and Szapary find that among the CEECs, only Hungary, Poland and Slovakia have achieved a high degree of synchronization with the 'old' EU countries (Darvas \& Szapáry, 2008) which is further confirmed by this study.

\section{MATERIAL AND METHODS}

The theoretical identification of unobservable shocks in the study is given by the aggregate supply-aggregate demand model (AS-AD). This model grasps both static (short-run) and dynamic dependencies between the aggregate production $(y)$ and prices $(p)$. The upward-sloping AS curve consists of the expected price level $\left(p^{e}\right)$ and the natural GDP $\left(y_{n}\right)$, and can be formulated as (Benigno, 2009):

$$
p-p^{e}=\frac{(1-\alpha)\left(\sigma^{-1}+\eta\right)}{\alpha}\left(y-y_{n}\right)
$$

where $\sigma$ denotes an elasticity of intertemporal substitution of consumption, and $\eta$ is a labour supply elasticity. The parameter $(1-\alpha)$ is interpreted as a fraction of firms adjusting prices to the profit-maximizing levels in a given period and allows for transitory rigidities (see Calvo, 1983). The downward-sloping AD curve depends on the natural levels of production and prices ${ }^{1}$, and may be shifted by either fiscal or monetary policies:

$$
y=\bar{y}+(g-\bar{g})-\sigma\left[i-(\bar{p}-p)-\left(\overline{\tau_{c}}-\tau_{c}\right)\right]-\sigma \ln \beta
$$

where $g$ denotes the volume of public expenditure, $i$ is a nominal interest rate, $\tau_{c}$ is a rate of consumption taxes, and $\beta$ is a households utility discount factor. AS shock in this identification scheme permanently influences both output and price levels. AD shock only temporarily changes the output that gradually returns to the long-run equilibrium.

According to the mainstream economic theory and the OCA theory, monetary policy can influence only aggregated demand shocks, ergo the problem of supply shocks is

\footnotetext{
${ }^{1}$ Bars in the equation (2) denote natural values of particular variables.
} 
beyond the scope of this paper ${ }^{2}$. The underlying AD shocks can be extracted in a specific version of the SVAR (Bayoumi \& Eichengreen, 1993; Blanchard \& Quah, 1989). The estimated system must be a representation of an infinite moving-average process of economic variables $\left(X_{t}\right)$ and economic shocks $\varepsilon_{t}$. For a bivariate AS-AD model, vector $X_{t}$ consists of the first differences of the basic variables: $\Delta y_{t}$ and $\Delta p_{t}$. Using the lag operator $L$, it can be re-written as:

$$
\left[\begin{array}{l}
\Delta y_{t} \\
\Delta p_{t}
\end{array}\right]=\sum_{i=0}^{\infty} L^{i}\left[\begin{array}{ll}
a_{11 i} & a_{12 i} \\
a_{21 i} & a_{22 i}
\end{array}\right]\left[\begin{array}{l}
\varepsilon_{d t} \\
\varepsilon_{s t}
\end{array}\right]
$$

with the underlying supply and demand shocks denoted respectively as $\varepsilon_{s t}$ and $\varepsilon_{d t}$. Assuming that both $\Delta y_{t}$ and $\Delta p_{t}$ are weakly stationary, and using the Wold's theorem, $X_{t}$ can be reduced to a standard vector-autoregression, in which estimated residuals for each dependent variable are $e_{y t}$ and $e_{p t}$. In order to transform this system into the structural model, we display residuals in terms of the structural shocks and impose four restrictions to properly identify the SVAR. The first two restrictions come from a regular normalization of variance of both shocks. The third one states that supply and demand shocks are independent. The fourth restriction is theory-based and comes directly from the AS-AD specification. If a demand shock only temporarily influences output, then its cumulative effect on the changes in output must be equal to zero. The last step of the specification involves additional qualitative (over-identifying) restrictions imposed on the model (Taylor, 2004).

The empirical estimation of the model covers quarterly data on real GDP and prices (GDP deflator) for the 23 European economies ${ }^{3}$. The data covering period 1995q2 to $2013 q 1$ was obtained from the Eurostat Database. Based on the ADF (Said \& Dickey, 1984) and KPSS (Kwiatkowski, Phillips, Schmidt \& Shin, 1992) tests, we conclude that both output and prices for every country in the sample are I(1) processes ${ }^{4}$, and the model can be estimated with four lags. Diagnostic tests applied to residuals (e.g. normality, auto-correlation) showed no clear statistical evidence to reject the models.

\section{RESULTS AND DISCUSSION}

The average values of correlation coefficient for demand disturbances were calculated for the entire period. Taking into account different geographical areas, correlation coefficients were computed for the whole sample (whole), euro area (ea), core countries $^{5}$ (core), peripheral countries $^{6}$ (per), core and periphery ${ }^{7}$ (core-per), and V4 countries (Table 1). This analysis revealed unexpected results. The average correlation of

\footnotetext{
${ }^{2}$ All the results for supply shocks are available upon request.

${ }^{3}$ Austria, Belgium, Cyprus, the Czech Republic, Denmark, Estonia, Finland, France, Germany, Greece, Hungary, Italy, Latvia, Lithuania, Luxembourg, the Netherlands, Poland, Portugal, the Slovak Republic, Slovenia, Spain, Sweden, the United Kingdom. The reliable time-series for Bulgaria, Croatia, Ireland, Malta and Romania do not cover the entire period of 1995-2013.

${ }^{4}$ All the time-series statistics are available upon request.

${ }^{5}$ Austria, Belgium, France, Germany, Italy, Luxembourg and the Netherlands.

${ }^{6}$ Cyprus, Finland, Greece, Portugal, the Slovak Republic, Slovenia and Spain.

${ }^{7}$ Excluding correlations within core and within periphery groups, e.g. Germany and Greece, but not Germany and France nor Greece and Spain.
} 
shocks among V4 countries is the highest (0.243) among all considered samples. The value of this coefficient is 0.2 higher than the one for entire sample. Even core countries of the euro area are characterized by lower value of mean demand shock correlation coefficient (0.137). Demand shocks similarity among all the members of the EMU is considerably lower. The lowest value of coefficient was obtained for the EMU periphery countries (-0.028), what brings about the notion of high heterogeneity among those countries. The corresponding measure for core-periphery sample is 0.01 , what suggests that monetary policy appropriate for core countries might not be in the best interest of periphery. This result implies that among the chosen sub-samples V4 countries are best candidates to form a monetary union. Very high correlation of shocks among V4 countries implies that a common monetary authority should be able to effectively implement monetary policy that may serve the interest of the entire area.

Table 1. Descriptive statistics of correlation coefficients of demand shocks for of EU countries (1996q2-2013q1)

\begin{tabular}{|l|r|r|r|r|r|r|}
\hline \multicolumn{1}{|c|}{ Sample } & whole sample & euro area & core & periphery & core-periphery & V4 countries \\
\hline Mean & 0.041 & 0.025 & 0.137 & -0.028 & 0.01 & 0.243 \\
\hline Median & 0.04 & 0.022 & 0.137 & -0.043 & 0.002 & 0.259 \\
\hline Maximum & 0.677 & 0.451 & 0.451 & 0.265 & 0.436 & 0.494 \\
\hline Minimum & -0.403 & -0.287 & -0.135 & -0.287 & -0.248 & 0.070 \\
\hline Standard Deviation & 0.165 & 0.15 & 0.144 & 0.134 & 0.141 & 0.151 \\
\hline Observations & 253 & 105 & 21 & 28 & 56 & 6 \\
\hline
\end{tabular}

Source: own calculations.

The analysis of demand shocks similarity using pairs of countries brings about very clear-cut conclusions (Table 2). Firstly, Poland and the Czech Republic are characterized by an extremely high correlation coefficient of demand shocks (0.494), which implies that they are eligible candidates for a monetary union formation. Secondly, in the case of the Czech Republic, the two best candidates for a common currency introduction are, respectively, Poland and Hungary (0.269), and in the case of Hungary, Poland (0.264) and the Czech Republic (0.269). Taking into consideration the fact that regarding Poland, Hungary is the third country with the highest correlation coefficient, one may conclude that these three countries are eligible candidates to form an efficiently functioning monetary union. The situation, however, is different in case of Slovakia which is characterized by a relatively high correlation coefficient of demand shocks only with Poland (0.255), and by rather low ones with the Czech Republic (0.070) and Hungary (0.105).

Pairwise correlations were also calculated for 15 EMU countries in the sample, with exception of previously analyzed Slovakia. Mean values of correlation coefficient for Austria with the entire sample, the euro area and core countries are respectively 0.00 , 0.01 and 0.07 (Table 3). This indicates that Austria has unfavourable perspectives for successful monetary union formation, even though it is characterized by relatively high values of coefficient with Finland, France and Germany. The situation is much more suitable for Belgium with respective mean values equal to $0.12,0.13$ and 0.17 . Cyprus has a mean value of -0.01 for correlation coefficient with core countries. This indicates that optimal monetary policy for core countries may not be adequate for the Cypriot 
economy. The case of Estonia is very similar to Cyprus - the country has a low capability for successful monetary union formation. The one exception is an extremely high value of correlation coefficient with the United Kingdom (0.68). Finland also presents rather poor perspectives for participation in monetary union. Highest values for this country are above 0.2 and the three top candidates are from outside of the Eurozone.

Table 2. Pairwise correlation coefficients of demand shocks of V4 with EU countries (1996q22013q1)

\begin{tabular}{|c|c|c|c|c|c|c|c|}
\hline \multicolumn{2}{|c|}{ Poland } & \multicolumn{2}{|c|}{ Hungary } & \multicolumn{2}{|c|}{ Czech Republic } & \multicolumn{2}{|c|}{ Slovakia } \\
\hline Country & $r$ & Country & $r$ & Country & $r$ & Country & $r$ \\
\hline Czech & 0.494 & Czech & 0.269 & Poland & 0.494 & Belgium & 0.436 \\
\hline Denmark & 0.330 & Poland & 0.264 & Hungary & 0.269 & Cyprus & 0.265 \\
\hline Hungary & 0.264 & Finland & 0.231 & Finland & 0.191 & Poland & 0.255 \\
\hline Latvia & 0.258 & Greece & 0.176 & Denmark & 0.183 & Lithuania & 0.185 \\
\hline Slovakia & 0.255 & Cyprus & 0.157 & Belgium & 0.154 & Latvia & 0.153 \\
\hline Sweden & 0.251 & Sweden & 0.150 & Slovenia & 0.148 & Hungary & 0.105 \\
\hline Finland & 0.249 & Latvia & 0.142 & Austria & 0.102 & Greece & 0.096 \\
\hline Belgium & 0.238 & Germany & 0.139 & Lithuania & 0.102 & Denmark & 0.081 \\
\hline Cyprus & 0.237 & Lithuania & 0.108 & Netherlands & 0.086 & Spain & 0.081 \\
\hline Lithuania & 0.194 & Slovakia & 0.105 & Portugal & 0.072 & Finland & 0.075 \\
\hline Greece & 0.149 & Denmark & 0.077 & Slovakia & 0.070 & Czech & 0.070 \\
\hline Germany & 0.134 & Portugal & 0.069 & Germany & 0.062 & France & 0.062 \\
\hline France & 0.127 & UK & 0.066 & Greece & 0.022 & Sweden & 0.023 \\
\hline Netherlands & 0.061 & Estonia & 0.029 & Sweden & 0.004 & Netherlands & -0.010 \\
\hline Austria & 0.040 & Slovenia & -0.004 & France & -0.036 & Portugal & -0.019 \\
\hline UK & 0.001 & Belgium & -0.008 & UK & -0.048 & UK & -0.048 \\
\hline Spain & -0.007 & Italy & -0.012 & Italy & -0.064 & Italy & -0.050 \\
\hline Luxembourg & -0.029 & Netherlands & -0.078 & Spain & -0.108 & Germany & -0.052 \\
\hline Italy & -0.070 & France & -0.094 & Cyprus & -0.114 & Austria & -0.063 \\
\hline Portugal & -0.088 & Luxembourg & -0.119 & Estonia & -0.124 & Estonia & -0.082 \\
\hline Estonia & -0.100 & Spain & -0.157 & Latvia & -0.141 & Slovenia & -0.132 \\
\hline Slovenia & -0.113 & Austria & -0.193 & Luxembourg & -0.151 & Luxembourg & -0.179 \\
\hline mean & 0.131 & mean & 0.060 & mean & 0.053 & mean & 0.057 \\
\hline
\end{tabular}

Source: own calculations.

The average values of correlation coefficient for France with the entire sample, the euro area and core countries are respectively $0.11 ; 0.14$ and 0.28 , which indicates that France can successfully form a monetary union, particularly with the core countries (Table 4). Respective values for Spain are $-0.03,0.00$ and 0.11 , what leads to an opposite conclusion. Latvia has extremely high value of correlation coefficient with Lithuania, what could be explained by their proximity. Best candidates to form an optimum currency area with Germany can be found among core countries, although values of correlation coefficient are only moderate. Greece is characterized by negative correlations both with euro area (-0.02) and core countries $(-0.05)$.

Two best candidates for monetary union formation with Italy are Slovenia and Spain, yet even in the case of this countries shocks correlations are rather small (Table 5). Mean values for Italy are close to zero, what is also true for Luxembourg. On the other hand, Luxembourg reveals a rather high shock similarity with other core countries, even though two best candidates for Luxembourg are from outside the EMU. The Netherlands is characterized by close to zero mean values with the entire sample, as well as with the 
EMU, and rather high with the core countries. Taken together, the Netherlands and France seem to be exceptionally good candidates to form a monetary union. Mean values for Portugal are all negative and the country is characterized by the highest demand shock similarity with Austria (0.16). This result indicates that Portugal should not seek monetary unification with any of analyzed countries. Much like the Netherlands, Slovenia is characterized by the average values of coefficients close to zero, with the entire sample and the Eurozone, but rather high with the core countries. Two best candidates for monetary union with Slovenia are Italy and the Netherlands.

Table 3. Pairwise correlation coefficients of demand shocks of Austria, Belgium, Cyprus, Estonia and Finland with EU countries (1996q2-2013q1)

\begin{tabular}{|c|c|c|c|c|c|c|c|c|c|}
\hline \multicolumn{2}{|c|}{ Austria } & \multicolumn{2}{|c|}{ Belgium } & \multicolumn{2}{|c|}{ Cyprus } & \multicolumn{2}{|c|}{ Estonia } & \multicolumn{2}{|c|}{ Finland } \\
\hline Partner & $r$ & Partner & $r$ & Partner & $r$ & Partner & $r$ & Partner & $r$ \\
\hline Finland & 0.207 & Slovakia & 0.436 & Latvia & 0.361 & UK & 0.677 & Poland & 0.249 \\
\hline France & 0.200 & Denmark & 0.349 & Slovakia & 0.265 & Lithuania & 0.091 & Denmark & 0.234 \\
\hline Germany & 0.193 & France & 0.339 & Lithuania & 0.263 & Latvia & 0.074 & Hungary & 0.231 \\
\hline Portugal & 0.115 & Netherlands & 0.268 & Poland & 0.237 & Hungary & 0.029 & Netherlands & 0.210 \\
\hline Belgium & 0.110 & Poland & 0.238 & Greece & 0.178 & Cyprus & -0.010 & Austria & 0.207 \\
\hline Czech & 0.102 & Finland & 0.195 & Hungary & 0.157 & Luxembourg & -0.027 & Belgium & 0.195 \\
\hline Spain & 0.084 & Czech & 0.154 & Sweden & 0.111 & Greece & -0.037 & Czech & 0.191 \\
\hline Netherlands & 0.060 & Slovenia & 0.148 & UK & 0.083 & Germany & -0.048 & UK & 0.187 \\
\hline Poland & 0.040 & Germany & 0.147 & Germany & 0.043 & Finland & -0.053 & Sweden & 0.168 \\
\hline Sweden & 0.030 & Luxembourg & 0.137 & Denmark & 0.033 & Italy & -0.056 & France & 0.151 \\
\hline UK & -0.006 & Austria & 0.110 & Belgium & 0.031 & Belgium & -0.060 & Slovenia & 0.142 \\
\hline Denmark & -0.016 & Latvia & 0.102 & Estonia & \begin{tabular}{|l|}
-0.010 \\
\end{tabular} & Sweden & -0.061 & Latvia & 0.139 \\
\hline Luxembourg & -0.020 & Sweden & 0.096 & Portugal & -0.050 & Slovakia & -0.082 & Germany & 0.086 \\
\hline Slovenia & -0.028 & Portugal & 0.068 & France & -0.055 & Poland & -0.100 & Slovakia & 0.075 \\
\hline Slovakia & -0.063 & Spain & 0.060 & Czech & -0.114 & Slovenia & -0.106 & Greece & 0.055 \\
\hline Latvia & -0.071 & UK & 0.038 & Italy & -0.118 & Netherlands & -0.111 & Italy & 0.051 \\
\hline Italy & -0.099 & Italy & 0.032 & Slovenia & -0.118 & Czech & -0.124 & Portugal & 0.041 \\
\hline Lithuania & -0.117 & Cyprus & 0.031 & Spain & \begin{tabular}{|l|}
-0.122 \\
\end{tabular} & Austria & -0.137 & Lithuania & -0.041 \\
\hline Estonia & -0.137 & Hungary & -0.008 & Finland & \begin{tabular}{|l|}
-0.132 \\
\end{tabular} & Portugal & -0.146 & Estonia & -0.053 \\
\hline Cyprus & -0.179 & Estonia & -0.060 & Luxembourg & -0.149 & France & -0.187 & Spain & -0.116 \\
\hline Hungary & -0.193 & Lithuania & -0.088 & Austria & -0.179 & Denmark & -0.246 & Cyprus & -0.132 \\
\hline Greece & -0.205 & Greece & -0.096 & Netherlands & -0.248 & Spain & -0.287 & Luxembourg & -0.182 \\
\hline Mean & 0.000 & mean & 0.123 & mean & 0.021 & mean & -0.046 & mean & 0.095 \\
\hline EU mean & 0.011 & EU mean & 0.128 & EU mean & \begin{tabular}{|l|}
-0.020 \\
\end{tabular} & EU mean & -0.085 & EU mean & 0.058 \\
\hline core mean & 0.074 & core mean & 0.172 & core mean & -0.097 & core mean & -0.089 & core mean & 0.103 \\
\hline
\end{tabular}

Source: own calculations.

The results of a dynamic approach are presented as a 9-element rolling window of correlation coefficient (Figure 1). The analysis of pairwise correlation coefficients reveals no tendencies over time with respect to demand shock similarity. Although, one can observe a sharp increase in values of correlation for early stages of the crisis and the downturn right afterwards (ca. 2007-2009). This might indicate that the economies of V4 countries reacted similarly at the beginning of the crisis, but due to differences in economic fundamentals and implemented policies they subsequently diverged. The investigation of the average values of correlation coefficients for V4 and the EMU brings clear evidence that, during the entire period, demand shock similarity among V4 countries was considerably higher than for the EMU. This indicates that the V4 is closer 
to being an optimum currency area than the EMU. V4 mean correlations are characterized by a higher variability which can be attributed to relatively small size of the sample comparing with the Eurozone.

Table 4. Pairwise correlation coefficients of demand shocks of France, Spain, Latvia, Germany and Greece with EU countries (1996q2-2013q1)

\begin{tabular}{|c|c|c|c|c|c|c|c|c|c|}
\hline \multicolumn{2}{|c|}{ France } & \multicolumn{2}{|c|}{ Spain } & \multicolumn{2}{|c|}{ Latvia } & \multicolumn{2}{|c|}{ Germany } & \multicolumn{2}{|c|}{ Greece } \\
\hline Partner & $r$ & Partner & $r$ & Partner & $\mathbf{r}$ & Partner & $\mathbf{r}$ & Partner & $r$ \\
\hline Denmark & 0.463 & Denmark & 0.205 & Lithuania & 0.509 & France & 0.342 & Latvia & 0.335 \\
\hline Netherlands & 0.451 & France & 0.200 & Cyprus & 0.361 & Denmark & 0.205 & Sweden & 0.332 \\
\hline Germany & 0.342 & Slovenia & 0.180 & Greece & 0.335 & Austria & 0.193 & Lithuania & 0.301 \\
\hline Belgium & 0.339 & Italy & 0.170 & Poland & 0.258 & Netherlands & 0.174 & Cyprus & 0.178 \\
\hline Luxembourg & 0.218 & Luxembourg & 0.128 & Slovakia & 0.153 & Luxembourg & 0.174 & Hungary & 0.176 \\
\hline Austria & 0.200 & Netherlands & 0.091 & Hungary & 0.142 & Belgium & 0.147 & Poland & 0.149 \\
\hline Spain & 0.200 & Austria & 0.084 & UK & 0.140 & Hungary & 0.139 & France & 0.123 \\
\hline Slovenia & 0.163 & Slovakia & 0.081 & Finland & 0.139 & Poland & 0.134 & Denmark & 0.116 \\
\hline Finland & 0.151 & Belgium & 0.060 & Sweden & 0.134 & Finland & 0.086 & Slovakia & 0.096 \\
\hline Poland & 0.127 & Portugal & 0.028 & Belgium & 0.102 & Czech & 0.062 & Finland & 0.055 \\
\hline Greece & 0.123 & Germany & 0.015 & Portugal & 0.086 & Cyprus & 0.043 & UK & 0.040 \\
\hline Sweden & 0.115 & Poland & -0.007 & Estonia & 0.074 & Slovenia & 0.022 & Czech & 0.022 \\
\hline Italy & 0.112 & Sweden & -0.032 & France & -0.002 & Spain & 0.015 & Luxembourg & 0.016 \\
\hline Slovakia & 0.062 & Czech & -0.108 & Luxembourg & -0.010 & Italy & -0.008 & Italy & 0.016 \\
\hline Latvia & -0.002 & Finland & -0.116 & Denmark & -0.036 & Estonia & -0.048 & Estonia & -0.037 \\
\hline UK & -0.026 & Cyprus & -0.122 & Italy & -0.048 & Slovakia & -0.052 & Netherlands & -0.044 \\
\hline Czech & -0.036 & Hungary & -0.157 & Germany & -0.069 & Latvia & -0.069 & Portugal & -0.087 \\
\hline Portugal & -0.045 & UK & -0.234 & Austria & -0.071 & Portugal & -0.079 & Belgium & -0.096 \\
\hline Cyprus & -0.055 & Latvia & -0.253 & Czech & -0.141 & Sweden & -0.097 & Germany & -0.156 \\
\hline Hungary & -0.094 & Greece & -0.259 & Netherlands & -0.201 & UK & -0.141 & Austria & -0.205 \\
\hline Lithuania & -0.174 & Lithuania & -0.270 & Slovenia & -0.208 & Greece & -0.156 & Slovenia & -0.208 \\
\hline Estonia & -0.187 & Estonia & -0.287 & Spain & -0.253 & Lithuania & -0.274 & Spain & -0.259 \\
\hline mean & 0.111 & mean & -0.027 & mean & 0.063 & mean & 0.037 & mean & 0.039 \\
\hline EU mean & 0.138 & EU mean & 0.000 & EU mean & 0.026 & EU mean & 0.052 & EUmean & -0.018 \\
\hline core mean & 0.277 & core mean & 0.107 & core mean & -0.043 & core mean & 0.170 & core mean & -0.049 \\
\hline
\end{tabular}

Source: own calculations.

The employed SVAR model was then used to build impulse response functions of output to aggregate demand disturbances. The functions obtained both for the V4 countries and the Eurozone economies strictly fit the AS-AD framework, and confirm that demand shocks only temporarily influence output (Figure 2) ${ }^{8}$. Except for Slovakia, which converges towards the equilibrium substantially longer, the effects of demand shocks on output in the V4 Group gradually diminish, and GDP levels return to the steady state after around six quarters. For the remaining three economies, the strongest impacts of $A D$ shocks to GDP is observed after 2 or 3 quarters. The demand disturbances in other EU

\footnotetext{
${ }^{8}$ The impulse response functions for aggregate supply shocks are not reported, and available upon request.
} 
economies are considerably more idiosyncratic. There are examples of high sensitivity to shocks (Greece), their long-lasting persistence (France), and strong overshooting in the adjustment (Germany). Smaller countries (e.g. Austria, Finland) tend to experience shocks of significantly higher magnitude than larger economies (e.g. Italy, Germany). The values of reaction functions of these economies to demand shocks, as measured in the sixth quarter, are either above or below the level to which V4 economies converge. Altogether, even when compared to the major EMU economies, the V4 countries reveal relatively similar and flexible adjustment to demand shocks with absence of considerable volatility.

Table 5. Pairwise correlation coefficients of demand shocks of Italy, Luxembourg, Portugal and Slovenia with EU countries (1996q2-2013q1)

\begin{tabular}{|c|c|c|c|c|c|c|c|c|c|}
\hline \multicolumn{2}{|l|}{ Italy } & \multicolumn{2}{|c|}{ Luxembourg } & \multicolumn{2}{|c|}{ Netherlands } & \multicolumn{2}{|c|}{ Portugal } & \multicolumn{2}{|c|}{ Slovenia } \\
\hline Partner & $r$ & Partner & $r$ & Partner & $r$ & Partner & $\mathbf{r}$ & Partner & $r$ \\
\hline Slovenia & 0.282 & Sweden & 0.310 & France & 0.451 & Austria & 0.115 & Italy & 0.282 \\
\hline Spain & 0.170 & Denmark & 0.222 & Denmark & 0.328 & Italy & 0.091 & Netherlands & 0.218 \\
\hline France & 0.112 & France & 0.218 & Belgium & 0.268 & Latvia & 0.086 & Denmark & 0.202 \\
\hline Portugal & 0.091 & Germany & 0.174 & Slovenia & 0.218 & Czech & 0.072 & Spain & 0.180 \\
\hline Netherlands & 0.055 & Belgium & 0.137 & Finland & 0.210 & Hungary & 0.069 & France & 0.163 \\
\hline Finland & 0.051 & Spain & 0.128 & Germany & 0.174 & Belgium & 0.068 & Czech & 0.148 \\
\hline Denmark & 0.044 & Netherlands & 0.126 & Luxembourg & 0.126 & Finland & 0.041 & Belgium & 0.148 \\
\hline Belgium & 0.032 & Greece & 0.016 & Spain & 0.091 & Slovenia & 0.040 & Finland & 0.142 \\
\hline Greece & 0.016 & Lithuania & 0.012 & Czech & 0.086 & Spain & 0.028 & Portugal & 0.040 \\
\hline Germany & -0.008 & Latvia & -0.010 & Poland & 0.061 & Slovakia & -0.019 & Germany & 0.022 \\
\hline Hungary & -0.012 & Austria & -0.020 & Austria & 0.060 & France & -0.045 & Hungary & -0.004 \\
\hline UK & -0.018 & Estonia & -0.027 & Italy & 0.055 & Cyprus & -0.050 & Austria & -0.028 \\
\hline Latvia & -0.048 & Poland & -0.029 & UK & 0.044 & Sweden & -0.067 & Luxembourg & -0.074 \\
\hline Slovakia & -0.050 & Slovenia & -0.074 & Slovakia & -0.010 & Germany & -0.079 & Estonia & -0.106 \\
\hline Estonia & -0.056 & Hungary & -0.119 & Greece & -0.044 & Lithuania & -0.086 & UK & -0.108 \\
\hline Czech & -0.064 & UK & -0.122 & Hungary & -0.078 & Greece & -0.087 & Poland & -0.113 \\
\hline Poland & -0.070 & Italy & -0.135 & Estonia & -0.111 & Poland & -0.088 & Sweden & -0.117 \\
\hline Austria & -0.099 & Cyprus & -0.149 & Portugal & -0.127 & UK & -0.091 & Cyprus & -0.118 \\
\hline Cyprus & -0.118 & Czech & -0.151 & Latvia & -0.201 & Netherlands & -0.127 & Slovakia & -0.132 \\
\hline Luxembourg & -0.135 & Portugal & -0.156 & Sweden & -0.236 & Estonia & -0.146 & Latvia & -0.208 \\
\hline Sweden & -0.149 & Slovakia & -0.179 & Cyprus & -0.248 & Luxembourg & -0.156 & Greece & -0.208 \\
\hline Lithuania & -0.176 & Finland & -0.182 & Lithuania & -0.403 & Denmark & -0.172 & Lithuania & -0.245 \\
\hline mean & -0.007 & mean & 0.000 & mean & 0.032 & mean & -0.027 & mean & 0.004 \\
\hline EU mean & 0.020 & EU mean & -0.009 & EU mean & 0.061 & EU mean & -0.016 & EU mean & 0.021 \\
\hline core mean & -0.027 & core mean & 0.061 & core mean & 0.145 & core mean & -0.019 & core mean & 0.104 \\
\hline
\end{tabular}

Source: own calculations 

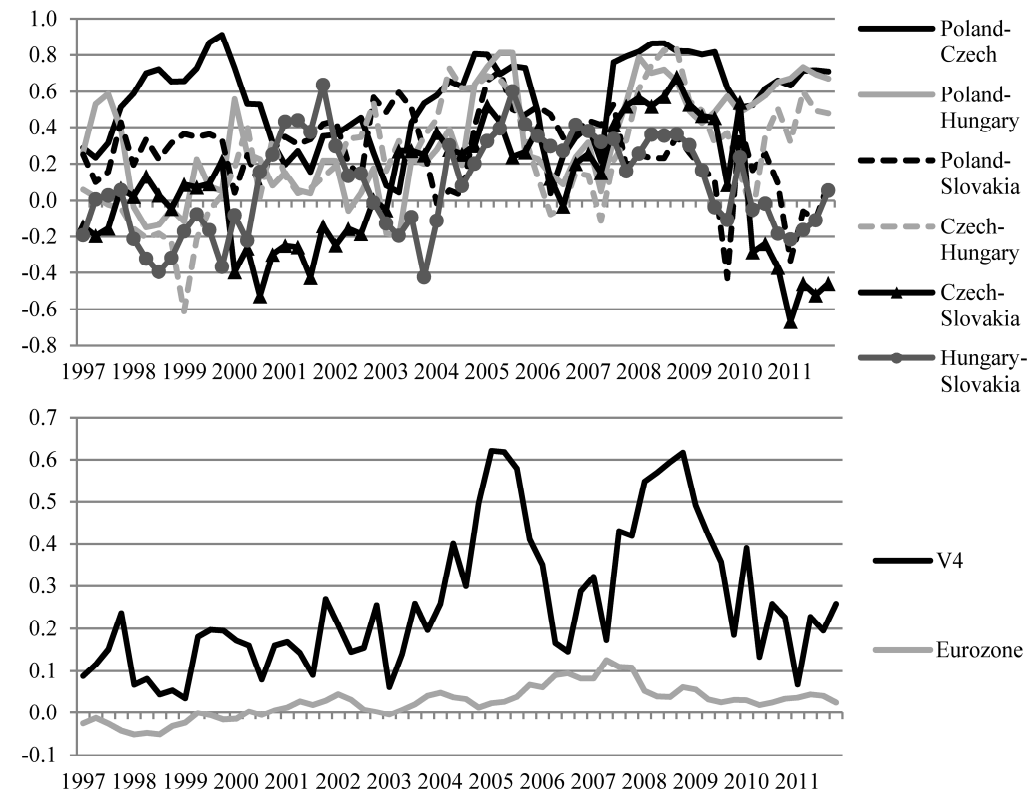

Figure 1. Pairwise correlations of demand shocks of V4 countries and average correlations of demand shocks of the Eurozone in a nine-element rolling window (1996q2-2013q1)

Source: own elaboration.
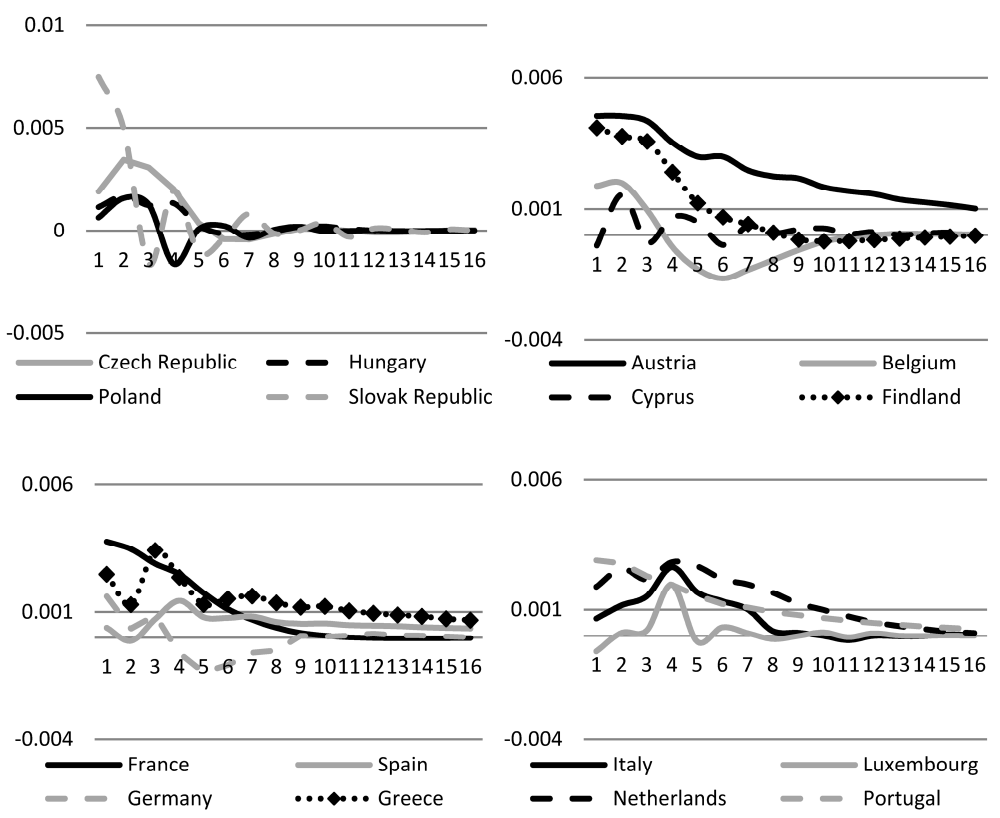

Figure 2. Demand shocks: impulse response functions of output in the V4 and selected Eurozone economies

Source: own elaboration. 


\section{CONCLUSIONS}

The goal of the paper was to assess the degree of similarities in macroeconomic demand disturbances between the V4 and EMU countries from 1995 to 2013. The coherence of this types of aggregate shocks among economies is one of the leading factors indicating whether the benefits associated with the adoption of a common currency outweigh its costs. Based on the SVAR model estimated for each country, we extracted underlying demand shocks, computed their correlations and measured adjustments of output to these shocks. First of all, the results suggest that the Eurozone is far from being an optimum currency area. With the exceptions of few outlying pairs of countries (e.g. France and the Netherlands), the distribution of demand shocks across states is significantly idiosyncratic. As a consequence, the possibility of an effective performance of the Eurozone as a whole is questionable. On the contrary, the V4 countries are characterized by higher demand shock similarity. Over the entire period of 1995-2013, the average value of correlation coefficients of demand disturbances within the V4 group was higher, not only when compared to the EMU, but also to the core Eurozone countries. This, in turn, along with the evidence derived from the impulse response functions analysis, indicates that common monetary policy might be more appropriate for the V4 rather than for the Eurozone economies.

\section{REFERENCES}

Baxter, M., \& Kouparitsas, M. (2005). Determinants of business cycle comovement: a robust analysis. Journal of Monetary Economics, Elsevier, 52(1), 113-157.

Bayoumi, T., \& Eichengreen, B. (1993). Shocking Aspects of European Monetary Integration. Torres, F., \& Giavazzi, F. (Eds.). Adjustment and growth in the European Monetary Union. Cambridge: Cambridge University Press.

Beck, K. (2014). Structural Similarity as a Determinant of Business Cycles Synchronization in the European Union: a Robust Analysis. Research in Economics and Business: Central and Eastern Europe, 5(2).

Benigno, P. (2009). New-Keynesian Economics: an AS-AD View. NBER Working Paper, 14824, 1-47.

Blanchard, O., \& Quah, D. (1989). The Dynamic Effects of Aggregate Supply and Demand Disturbances. American Economic Review, 79(4), 655-673.

Bordo, M., \& Helbling, T. (2011). International Business Cycle Synchronization In Historical Perspective. Manchester School, 79(2), 208-238.

Böwer, U., \& Guillemineau C. (2006). Determinants of Business Cycles Synchronization Across Euro Area Countries. EBC Working Paper, 587, 1-73.

Calvo, G. (1983). Staggered Prices in a Utility-Maximizing Framework. Journal of Monetary Economics, 12(3), 383-398.

Commission of the European Communities (1990). One market, one money. An evaluation of the potential benefits and costs of forming an economic and monetary union. European Economy, 44, 1-347.

de Grauwe, P., \& Mongelli, F.P. (2005). Endogeneities of Optimum Currency Areas. What Brings Countries Sharing a Single Currency Closer Together?. ECB Working Paper, 468, 1-40. 
Darvas, Z., \& Szapáry, G. (2008). Business Cycle Synchronization in the Enlarged EU, Open Economies Review, 19(1), 1-19.

Frankel J., \& Rose, A. (1998). The Endogeneity of the Optimum Currency Area Criteria, Economic Journal, 108(449), 1009-25.

Fidrmuc, J., \& Korhonen, I. (2006). Meta-analysis of the business cycle correlation between the euro area and the CEECs. Journal of Comparative Economics, 34(3), 518-537.

Fidrmuc, J., \& Korhonen, I. (2006). Meta-Analysis of the Business Cycle Correlation between the Euro Area and the CEECs. CESifo Working Paper Series, 1693, 1-27.

Imbs, J. (2004). Trade, Finance, Specialization, and Synchronization. Review of Economics and Statistics, 86(3), 723-734.

Kalemli-Ozcan, S., Papaioannou, E., \& Peydró, J.L. (2009). Financial Integration and Business Cycles Synchronization. CEPR Discussion Paper, 7292, 1-50.

Kenen, P. (1969). The Theory of Optimum Currency Areas: An Eclectic View. R. Mundell \& A. Swoboda (Eds.). Monetary Problems in the International Economy. Chicago, IL: University of Chicago Press, 41-60.

Krugman, P. (1993). Lessons of Massachusetts for EMU. F. Torres \& F.Giavazzi (Eds.). Adjustment and growth in the European Monetary Union. Cambridge: Cambridge University Press, 241261.

Kwiatkowski, D., Phillips, P., Schmidt, P., \& Shin, Y. (1992). Testing the Null Hypothesis of Stationarity against the Alternative of a Unit Root. Journal of Econometrics, 54(1), 159-178.

Lee, G. \& Azali, M. (2010). The Endogeneity of The Optimum Currency Area Criteria in East Asia. Economic Modelling, 27(1), 165-170.

Lehwald S. (2013). Has the Euro changed business cycle synchronization? Evidence from the core and the periphery, Empirica, 40(4), 655-684.

McKinnon, R. (1963). Optimum Currency Areas. American Economic Review, 53(1), 717-725.

Mundell, R. (1961). A Theory of Optimum Currency Areas. American Economic Review, 51(4), 657665.

Sachs, A., \& Schleer, F. (2013). Labour Market Institutions and Structural Reforms: A Source for Business Cycle Synchronization?. International Journal of Applied Economics, 10(1), 63-83.

Said, E., \& Dickey, D. (1984). Testing for Unit Roots in Autoregressive Moving Average Models of Unknown Order. Biometrika, 71(3), 599-607.

Siedschlag, I. (2010). Patterns and Determinants of Business Cycles Synchronization in Enlarged European and Monetary Union, Eastern Journal of European Studies, 1(1), 21-44.

Silvestre, J., Mendonca, A., \& Passos, J. (2007). The Shrinking Endogeneity of Optimum Currency Areas Criteria: Evidence from the European Monetary Union - A Beta Regression Approach. ISEG Working Paper, 22, 1-12.

Taylor, M.P. (2004). Estimating Structural Macroeconomic Shocks through Long-run Recursive Restrictions on Vector Autoregressive Models: the Problem of Identification. International Journal of Finance and Economics, 9(3), 229-244. 


\section{Authors}

The contribution of co-authors is equal and can be expressed as $50 \%$ each of the authors.

\section{Krzysztof Beck}

Research assistant in the Department of Economic at the Lazarski University, main interests: macroeconomics, mathematical economics, theory of optimum currency areas, applied econometrics.

\section{Jakub Janus}

Research assistant in the Department of Macroeconomics at the Cracow University of Economics, main interests: macroeconomics, monetary policy, central banking, macroeconometrics.

\section{Correspondence to:}

Mgr Jakub Janus (PhD Student)

Cracow University of Economic

Department of Macroeconomics

ul. Rakowicka 27, 31-510 Kraków, Poland

jakub.janus@uek.krakow.pl 
